\author{
Setiamurti Rahardjo \& Kiki Septias Pratiwi \\ Universitas Telkom \\ icusrahardjo@tcis.telkomuniversity.ac.id \\ kikiseptiasp@yahoo.co.id
}

\title{
PENERAPAN WAYFINDING DI KORIDOR KANTOR GALAMEDIA BANDUNG
}

\begin{abstract}
Abstrak: Kantor merupakan sarana bekerja untuk memberi pelayanan sesuai dengan bidangnya. Terdapat beberapa masalah dalam memanajemen ruang kantor yaitu desain interior terutama bagian koridor. Koridor merupakan sirkulasi publik yang berfungsi sebagai penghubung ruang satu dengan lainnya dan terkadang diabaikan dari segi desain interiornya. Kantor Galamedia Bandung merupakan salah satu kantor media cetak yang memiliki desain koridor monoton dari segi dinding, lantai dan langit-langit sehingga hal tersebut tidak tercipta identitas perusahaan dan karakteristik perusahaan. Identitas perusahaan merupakan bentuk wujud nyata dari perusahaan yang dapat diwujudkan melalui logo. Perwujudan pendukung desain interior tidak hanya disalurkan malalui bidang produk akan tetapi dapat diwujudkan melalui bidang grafis yaitu menerapkan wayfinding yang bertujuan untuk memberikan informasi petunjuk arah yang didukung dengan teks singkat, jelas dan padat dalam bentuk visual sehingga memudahkan pengguna publik dalam mencari lokasi yang dituju. Hal tersebut dapat dijadikan sebagai perwujudan identitas dan karakteristik ruang koridor kantor Galamedia dengan memanfaatkan logo perusahaan yang merupakan wujud nyata dalam bentuk visual. Penelitian ini menggunakan metode eksperimen dengan mengumpulkan data primer maupun sekunder sebagai sumber data yang akan dijadikan hasil akhir penelitian.Tujuan dari penelitian untuk memberikan solusi desain ruang koridor kantor Galamedia dengan memanfaatkan logo perusahaan yang disalurkan melalui wayfinding.
\end{abstract}

Kata Kunci : Koridor, Logo, Wayfinding

\begin{abstract}
Office work is a means to provide services in accordance with their fields. There are some problems in management of the office space is the interior design, especially the corridor. Corridor is a public circulation space that serves as a liaison with one another and sometimes overlooked in terms of interior design. Galamedia Office Bandung is one of the offices of print media that have monotonous corridor design in terms of walls, floor and ceiling so that it does not create a corporate identity and characteristics of the company. Corporate identity is a form of concrete manifestation of companies that can be realized through the logo. Embodiment supporters interior design is not only channeled through the field of the product but can be realized through the field of graphics that apply wayfinding which aims to provide information of directions are supported with brief texts, clearly and concisely in a visual form that allows users to the public in finding the intended location. It can be used as an embodiment of the identity and characteristics of Galamedia office corridor space by utilizing the company's logo which is a real form in a visual form. This study uses a experiment method to collect primary and secondary data as a data source that will be the end result of research. The purpose of research to provide design solutions Galamedia office corridor space by utilizing the company's logo are routed through wayfinding.
\end{abstract}

Keywords: Corridor, Logo, Wayfinding

\section{Pendahuluan}

\subsection{Pengertian}

Kantor merupakan tempat bekerja untuk mengurus pekerjaan dan memberi pelayanan yang sesuai di bidangnya. Di dalam memanajemen kantor, beberapa aspek perlu diperhatikan untuk meningkatkan kualitas kantor maupun pengguna. Salah satu bagian yang tidak dapat 
disepelekan adalah desain interior kantor, mengingat peranan aspek fisik ruang yang secara signifikan berpengaruh pada kepuasan para pekerja (Misoska, et al., 2014). Sayangnya, karena berbagai keterbatasan maupun berbagai alasan lainnya, seringkali penerapan desain interior pada kantor-kantor di Indonesia pada umumnya dan Bandung khususnya kurang diperhatikan secara menyeluruh. Pada kasus yang ditemukan di Kantor Galamedia, belum terlihat adanya pengaplikasian desain yang mencerminkan identitas perusahaan, terutama bagian koridor yang menjadi sirkulasi umum di area publik.

Berdasakan fungsinya sebagai penghubung antar ruang yang berada di area publik, sudah sewajarnya sebuah koridor utama dirancang dengan tema yang mencerminkan identitas perusahaan serta dapat menjadi pengarah sirkulasi (wayfinding) yang jelas bagi siapa pun yang mengaksesnya. Sementara itu, identitas perusahaan itu sendiri secara desain dapat dimunculkan melalui logo, yang baik secara simbolik maupun grafik akan menjadi tanda yang membedakan perusahaan satu dan lainnya (Adir, et al., 2012). Dengan demikian, secara mendasar, penerapan tema desain berdasarkan logo sebagai wayfinding merupakan bentuk nyata perwujudan identitas perusahaan secara visual.

\subsection{Studi Kasus}

Studi kasus yang dibahas pada penulisan ini adalah koridor kantor sebuah surat kabar Harian Umum Galamedia Bandung. Berdasarkan hasil observasi, didapati bahwa koridor kantor ini memiliki desain yang monoton pada bagian dinding, lantai dan langit-langit tanpa adanya identitas perusahaan dan penunjukan karakteristik kantor Galamedia. Sedangkan sesungguhnya kantor ini sudah memiliki logo yang memiliki arti sesuai dengan jenis kantornya sebagai kantor sebuah surat kabar, yaitu berani dan siap untuk memberikan informasi kepada masyarakat. Hal tersebut dapat dilihat dari tipografi "GALAMEDIA" menggunakan huruf abjad besar berwarna putih yang mengartikan kesiapan koran Galamedia dalam menyebarkan berita kepada masyarakat, sedangkan teks "EKSPRESI Greater Bandung" merupakan motto dari Galamedia yang mengartikan bahwa konten dan penyebaran koran Galamedia ditujukan se-Bandung Raya. Warna biru sebagai latar belakang tulisan Galamedia mengandung arti kepercayaan, dan warna kuning yang dimunculkan berupa garis pada bagian bawah merupakan penanda bahwa Galamedia merupakan mitra dari Grup Pikiran Rakyat.

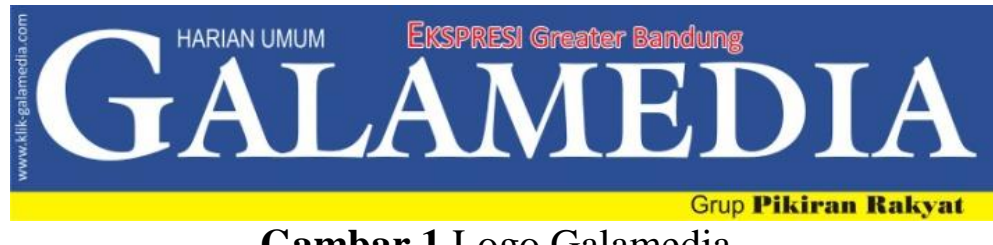

Gambar 1.Logo Galamedia

Dengan adanya perkembangan desain sekarang ini, penerapan desain di dalam ruangan tidak hanya disalurkan melalui pengelolaan furnitur maupun elemen-elemen pembentuk ruangnya, tetapi juga melalui aplikasi wayfinding yang terkait dengan bidang komunikasi visual. Hal tersebut ditujukan untuk memberikan informasi secara visual di dalam ruang publik dan dapat memudahkan pengguna dalam mencari ruangan yang dituju. Wayfinding merupakan salah satu perwujudan Environmental Graphic Design yang menerapkan petunjuk arah disertai konten informasi yang padat, singkat dan jelas. Dalam penerapannya, wayfinding dapat memberikan suasana yang sesuai dengan lingkup lingkungan disekitarnya. Hal tersebut dapat dikaitkan dengan studi kasus di dalam koridor kantor Galamedia yang memiliki desain monoton di beberapa bagian elemen interior. Maka dari itu, dibutuhkan solusi desain di dalam koridor 
kantor Galamedia dengan memanfaatkan logo perusahaan yang disalurkan melalui penerapan wayfinding sehingga menciptakan karakteristik dan identitas kantor.

\section{Landasan Teori}

\subsection{Wayfinding}

Sejak bertahun-tahun yang lalu, keberadaan desain grafis kerap kali ditemukan menyatu pada bangunan dan ikut berperan serta dalam aktivitas pengguna bangunan tersebut (Poulin, 2012:9). Salah satu contohnya adalah wayfinding, yang merupakan bagian dari Environmental Graphic Design yang berfungsi untuk memberikan informasi dan kemudahan kepada pengguna publik dalam mencari lokasi tertentu. Berdasarkan Salmi (2016), terdapat beberapa faktor yang menentukan desain wayfinding, di antaranya: organisasi spasial, landmark, signage, informasi directories, peta, serta warna dan pencahayaan; dimana pengolahan layout pada ruang merupakan hal yang fundamental. Signage, yang sering dikaitkan dengan wayfinding, adalah salah satu bentuk implementasinya yang paling mudah ditemui. Jika signage secara spesifik mengarahkan pengguna untuk menemukan tujuannya melalui tanda, maka wayfinding melibatkan aspek yang lebih dari itu, termasuk penataan lingkungan sekitarnya (Calori, 2016:6). Namun demikian, signage sebagai bagian dari wayfinding perlu diletakkan tegak lurus arah sirkulasi dan berada di atas ketinggian mata, terutama pada bangunan yang memiliki koridor (Salmi, 2016).

Sementara Coenen et.al (2016) memaparkan bahwa wayfinding, khususnya pada bangunan publik, harus memenuhi lima kriteria berikut:

- Memiliki kombinasi konten yang sesuai dengan fungsi dan memakan area penempatan minimum

- Memberikan petunjuk terhadap arah secara spasial untuk mencapai lokasi yang dituju

- Memiliki karakter yang dapat dipahami oleh berbagai penggunanya secara umum

- Mudah dilihat

- Memiliki ketepatan informasi yang terkait dengan waktu

\subsection{Logo}

Keberadaan logo pada sebuah perusahaan mutlak diperlukan sebagai salah satu pencitraan maupun penciptaan identitas perusahaan, salah satunya seperti yang dikutip oleh Adir, et.al. (2012), industri media adalah salah satu sektor dimana penggunaan logo dianggap penting. Dalam hal ini, sebuah kantor harian umum media cetak termasuk salah satunya. Secara mendasar, logo dimunculkan dalam rupa elemen grafis yang dipakai oleh suatu perusahaan untuk memunculkan ciri khasnya (Machado, 2015). Di samping faktor estetika yang dimunculkan oleh elemen grafis tersebut, fungsi utama dari sebuah logo adalah untuk memicu persepsi tahap awal untuk penciptaan branding dan menjadi suatu bentuk komunikasi visual yang cepat (Mihajlovic, et.al., 2016).

Logo merupakan salah satu identitas yang dijadikan sebagai bentuk nyata perusahaan serta dapat dikembangkan melalui penerapan bentuk estetika maupun visual. Hal ini juga dapat memberikan karakteristik dan menjadikan citra perusahaan menjadi lebih baik, sedangkan pengaruh bagi manusia akan lebih mudah menghafal dan mengingat bahwa logo perusahaan tersebut berbeda dengan logo perusahaan lainnya. Sehingga pada sebuah bangunan, penempatan logo perusahaan di area publik yang sering dilalui penggunanya akan menimbulkan persepsi baik dalam meningkatkan citra identitas perusahaan tersebut. 


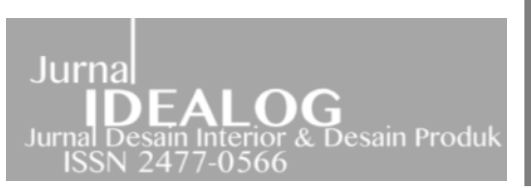

Jurnal I D E A L O G, IDE DAN DIALOG INDONESIA

Jurnal Desain Interior \& Desain Produk

Vol.1 No.3, September 2016

ISSN 2477 - 0566

\section{Metode Penelitian}

\subsection{Pengumpulan Data}

Terdapat beberapa langkah yang dilakukan dengan cara mengumpulkan sumber data primer dan sekunder untuk dianalisa lebih lanjut. Data primer terkait dengan wawancara dengan pihak terkait yaitu pegawai kantor yang ada di lokasi, survey sekaligus observasi lapangan untuk mendapatkan objek permasalahan dan perkembangan data yang sudah ada (kompetitor) maupun pengambilan data gambar lapangan, sedangkan data sekunder terkait dengan pembelajaran studi literatur berdasarkan topik penelitian.

\subsection{Analisa Data}

Data terkait penulisan ini diolah menggunakan metode kualitatif dengan implementasi metode eksperimen dalam analisa untuk mencapai simpulan. Menurut Sugiyono (2013:72), metode eksperimen adalah metode yang digunakan untuk mencari pengaruh perlakuan tertentu terhadap yang lain dalam kondisi yang terkendalikan. Jadi, metode ini memiliki percobaan terhadap objek dengan menggambarkan ilustrasi wayfinding pada interior koridor kantor Galamedia. Respon dari percobaan tersebut menjadi bahan analisa pada penelitian ini untuk mendapatkan hasil ada atau tidaknya hubungan sebab-akibat dengan cara mengaplikasikan wayfinding pada interior koridor kantor Galamedia.

\section{Hasil Pembahasan}

\subsection{Ruang Koridor Kantor Galamedia}

Setelah mengumpulkan beberapa data berdasarkan metode yang dilakukan, ruang koridor kantor Galamedia memiliki desain monoton karena hanya menerapkan warna biru sebagai pelapis warna dinding, keramik berwarna putih dan penggunaan gypsum berwarna putih pada langit-langit. Tidak hanya itu, koridor kantor Galamedia menerapkan tangga sebagai penghubung antara ruang satu dengan lainnya sehingga ruang-ruang tersebut dipisahkan dari lantai satu dengan lantai lainnya. Jika ditinjau kembali pada literatur acuan, kantor Galamedia tidak menciptakan identitas perusahaan di sepanjang koridor tersebut, sedangkan perwujudan identitas melalui desain interior sangat penting dalam memanajemen kantor untuk meningkatakan citra perusahaan maupun psikologi penggunanya.

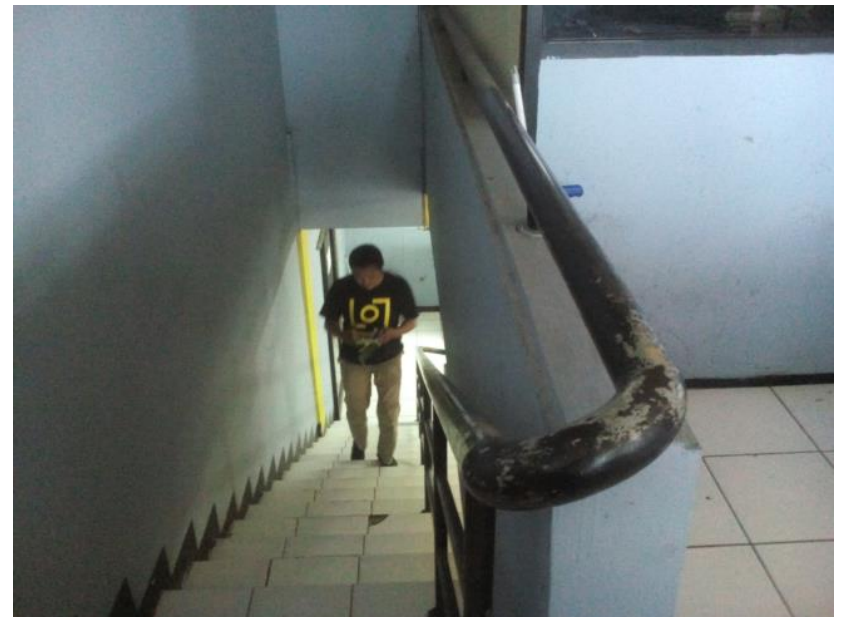

Gambar 4. Ruang Koridor Kantor Galamedia yang Memiliki Desain Monoton 
Ruang koridor memiliki salah satu elemen penting dalam mendukung terciptanya koridor yang baik yaitu kenyamanan dan identitas. Kenyamanan di dalam ruang koridor dipengaruhi dengan adanya beberapa fasilitas seperti tempat duduk terlebih jika koridor memiliki jangkauan yang panjang. Sedangkan identitas merupakan wujud lokal dari lingkup sekitar yang dapat menunjukan karakteristik dan identitas koridor. Dari hal tersebut, ruang koridor Galamedia dapat didukung dengan menciptakan desain yang sesuai dan memberikan nilai tambah agar ruang tidak monoton serta mewujudkan identitas perusahaan.

\subsection{Penggunaan Logo Galamedia sebagai Identitas Perusahaan}

Jika ditinjau dari segi kebutuhan branding perusahaan, logo dapat mewakili adanya identitas dan karakteristik karena sesuai dengan maknanya bahwa logo merupakan hasil wujud nyata dari apa yang dimiliki oleh perusahaan tersebut. Secara mendasar, logo diciptakan sebagai wadah promosi yang kaitannya dengan kondisi perusahaan tersebut dari segi pelayanan sesuai bidangnya. Apabila dikaitkan dengan studi kasus, logo Galamedia sudah memiliki makna yang sesuai dengan perwujudan nyata di bidangnya, akan tetapi tidak diterapkan secara maksimal untuk menciptakan identitas dan karakteristik perusahaan. Artinya, logo Galamedia hanya disampaikan pada bagian eksternal, seperti penampilan pada halaman depan koran maupun secara online, sedangkan penerapan bagian internal yang meliputi ruang lingkup kantor terutama pada elemen desain interior tidak disampaikan dalam bentuk estetika maupun visual yaitu hanya menggunakan warna biru pada dinding sebagai salah satu branding color company Galamedia. Apabila ada perwujudan lain seperti memasukan bidang desain grafis ke dalam interior, maka identitas Galamedia akan terwujud nyata dan dapat disampaikan pada ruang koridor sehingga tidak monoton serta dampak bagi pengguna akan lebih mudah mengetahui karakteristik kantor Galamedia.

\subsection{Pengaplikasian Wayfinding di dalam Ruang Koridor Kantor Galamedia}

Penerapan desain interior tidak hanya disampaikan melalui penerapan konsep ruang, tetapi juga dapat dikembangkan melalui bidang grafis, yaitu wayfinding. Penyaluran desain interior melalui bidang grafis ini bertujuan untuk memberikan petunjuk arah sesuai dengan tata letak ruang yang didukung dengan teks padat, jelas dan singkat. Hal tersebut akan memudahkan pengguna publik dalam mencari lokasi yang dituju. Wayfinding sangat baik diterapkan di area publik seperti ruang koridor kantor Galamedia, karena akan banyak orang yang melintasi area tersebut untuk menuju ruang satu ke ruang lainnya. Penerapan wayfinding memiliki 3 komponen penting dalam pembentukannya, yaitu sistem informasi konten, sistem grafis dan sistem perangkat keras. Apabila studi kasus disesuaikan dengan penerapan komponen wayfinding di dalam ruang koridor, antara lain:

\section{a. Lokasi dan Konten}

Lokasi yang akan menjadi objek penempatan papan wayfinding berada di lantai 2, karena tujuan yang diarahkan adalah ruang-ruang di lantai 3. (Gambar.5). Sedangkan konten yang diinformasikan yaitu ruang produksi, ruang SDM, toilet dan mushola. Alasan pemilihan informasi ruang di lantai 3 karena memiliki ruang yang lebih banyak dibandingkan ruang yang ada pada lantai sebelumnya. Tidak hanya itu, terdapat beberapa area servis seperti toilet dan mushola yang memungkinkan pengguna publik akan lebih banyak menggunakan ruang layanan tersebut.(Gambar.6) 


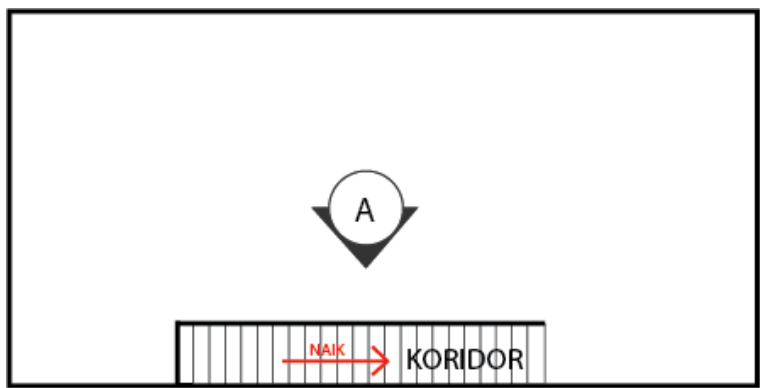

Lantai 2

Kantor Galamedia Bandung

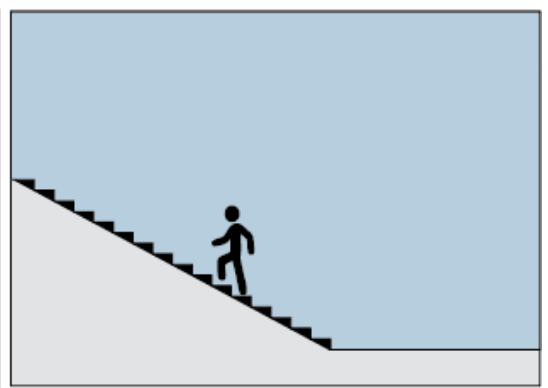

Gambar Tampak A

Gambar 5. Tampak Dinding Lantai 2 Kantor Galamedia sebagai Penempatan Papan Wayfinding

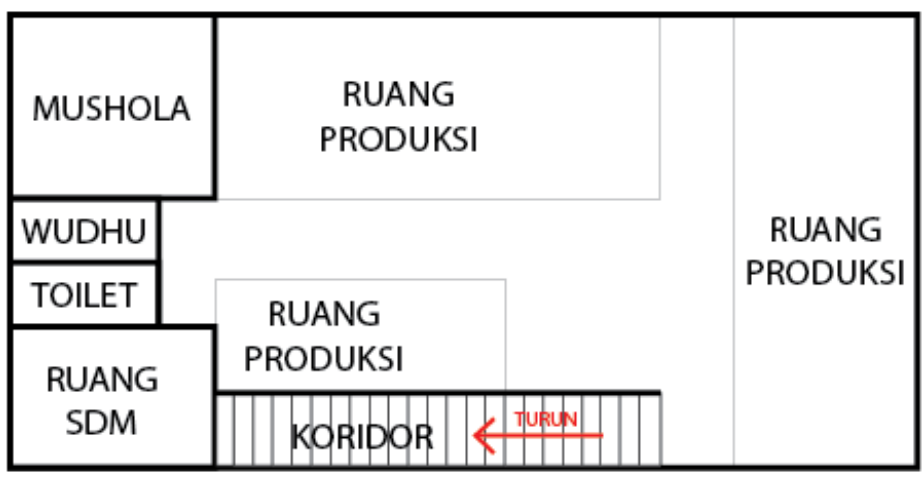

Lantai 3

Kantor Galamedia Bandung

Gambar 6. Denah Ruang Lantai 3 sebagai Konten Informasi Papan Wayfinding

b. Bentuk Layout

Dengan penyesuaian bentuk dinding yang ada di lapangan, maka bentuk yang lebih baik diterapkan yaitu persegi panjang yang memiliki sudut tajam. Hal tersebut menyesuaikan kondisi bentuk di lapangan sehingga membentuk persegi panjang sebagai papan informasi.

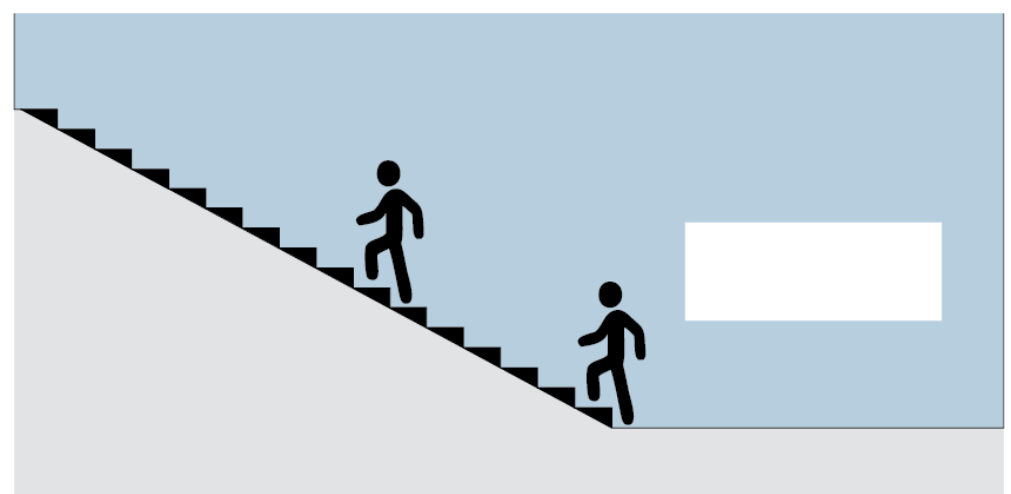

Gambar7. Bentuk Layout Wayfinding pada Dinding Koridor Kantor Galamedia Lantai 2

c. Sistem Desain Grafis

Sistem desain grafis merupakan sistem yang membentuk karakteristik wayfinding untuk area tertentu. Dalam penerapannya, sistem yang digunakan yaitu dengan petunjuk arah yang sesuai dengan tata letak ruang dan teks yang mewakili informasi mengenai ruang yang akan 


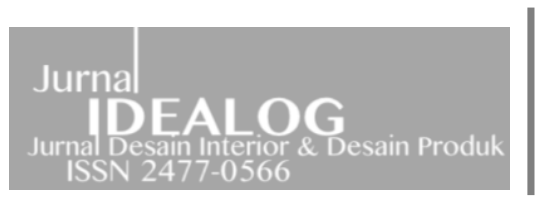

diinformasikan. Penerapan tersebutdapat memanfaatkan logo perusahaan karena pada awalanya terbentuk melalui konsep yang sesuai dan mewakili wujud perusahaan. Logo dapat dimanfaatkan dari segi branding color company ataupun logo type yang dapat memberikan identitas perusahaan. Sesuai dengan pemanfaatan warna perusahaan Galamedia, warna yang diambil yaitu biru dan kuning. Warna tersebut memiliki makna yang jelas tentang perwujudan Galamedia secara tidak langsung. Tidak hanya itu, pengaplikasian warna harus dipertimbangkan agar tidak saling tindih sehingga informasi yang disampaikan jelas. Sedangkan untuk pengaplikasian teks menggunakan type font "GALAMEDIA" yaitu Adobe Garamond Pro dan pengaplikasian visual petunjuk arah menggunakan bentuk tajam dan menunjukan arah ke atas, karena menyesuaikan koridor Galamedia yang memiliki tangga menuju ke ruang atas.

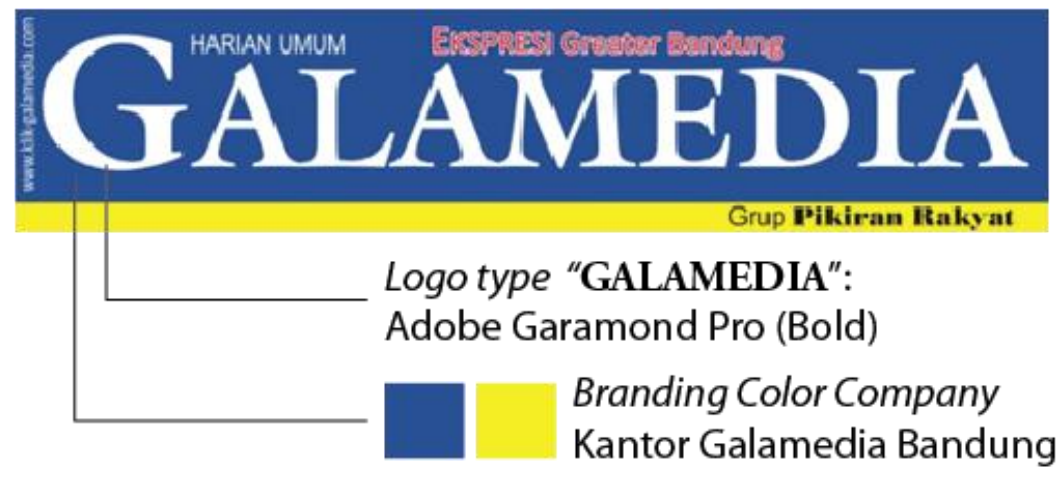

Gambar 8.Identitas Warna dan Logo Type Galamedia

d. Material

Penggunaan material disesuaikan dengan peletakan wayfinding karena hal tersebut akan mempengaruhi perawatan dan kualitas informasi yang disampaikan. Sesuai dengan studi kasus, maka material yang lebih baik digunakan yaitu kaca transparan dengan laminasi plastik (waterproof sticker). Pemilihan material kaca sebagai latar belakang informasi ditujukan untuk melindungi dinding kantor yang memungkingkan dalam mengubah warna catatau perubahan lainnya. Tidak hanya itu, sebagai komponen pendukung dalam pemasangan kaca yaitu sekrup dengan material stainless steel yang ditujukan sebagai konstruksi antara dinding dengan kaca. Pemilihan laminasi stiker (waterproof sticker) ditujukan untuk memudahkan pemasangan maupun pelepasan yang memungkinkan adanya kecenderungan pemindahan informasi tata letak ruang kantor Galamedia sehingga dalam perawatannya juga mudah diaplikasikan. Selain itu, penggunaan material laminasi plastik juga ditujukan untuk melindungi papan informasi dari kotoran seperti debu. Tidak hanya itu, perawatan juga akan lebih mudah yaitu hanya dengan membersihkan menggunakan air dan cairan pembersih debu. Dengan adanya pemilihan material tersebut juga mendukung konsep perkembangan kantor dan isi berita Galamedia yang mengikuti zaman (up to date) terlebih pada informasi koran yang setiap harinya disebarkan se-Bandung Raya.

\subsection{Hasil Usulan Desain Wayfinding pada Dinding Koridor Kantor Galamedia}

Untuk menyesuaikan desain wayfinding dengan logo Galamedia, maka terdapat 3 usulan desain yang mendekati hal tersebut, yaitu: 

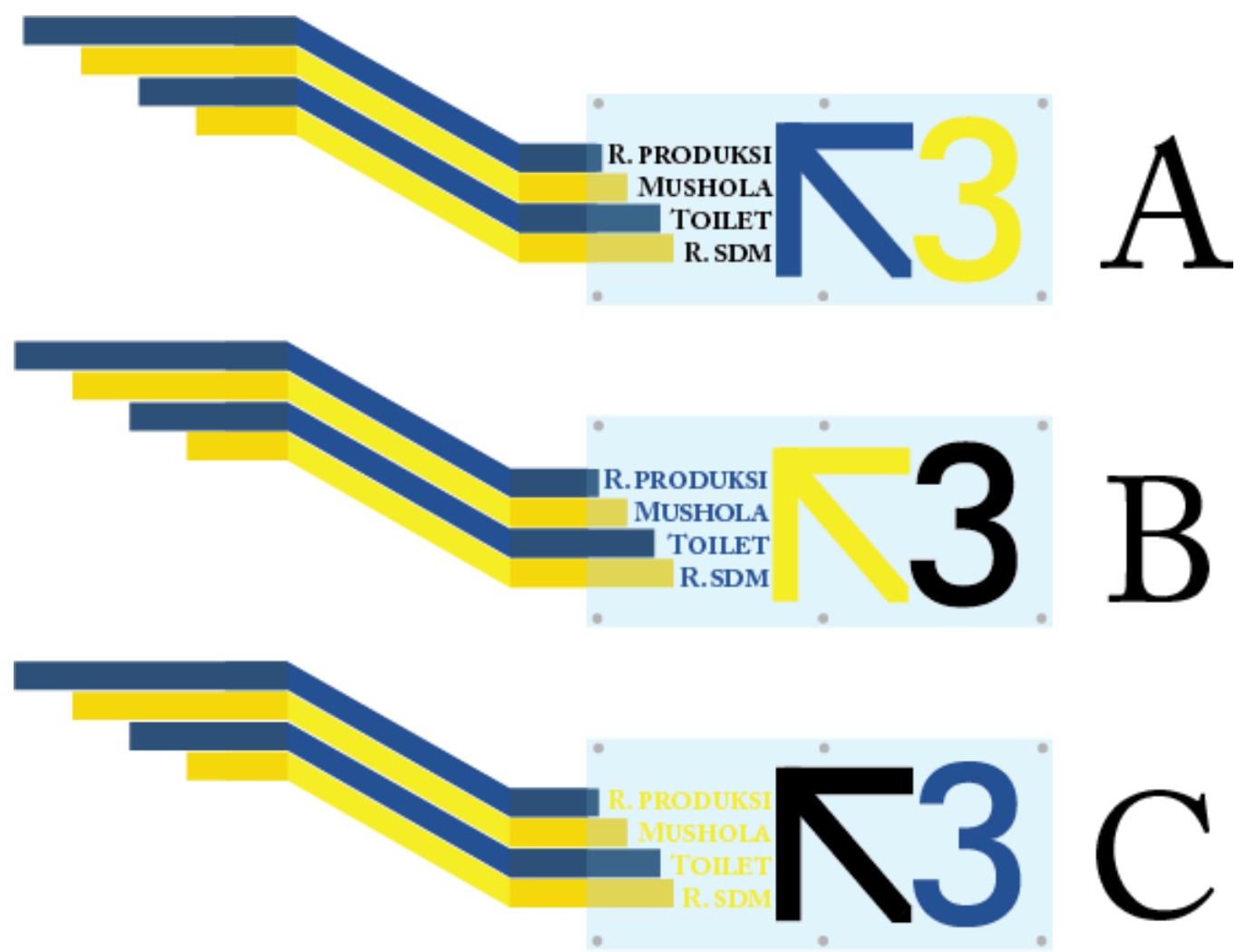

Gambar 9. Hasil Usulan Desain Wayfinding pada Dinding Koridor Kantor Galamedia

Pada gambar diatas, dapat dijelaskan bahwa dari ketiga desain tersebut saling mendekati dengan penerapan logo Galamedia yang digunakan. Akan tetapi yang lebih mendekati dengan objek yaitu wayfinding A, hal tersebut dikarenakan penggunaan warna yang sama dengan logo Galamedia. Pemilihan warna hitam pada teks konten ditujukan untuk menegaskan informasi, sedangkan warna biru dan kuning pada petunjuk arah dan informasi lantai ditujukan mendukung konten informasi yang disesuaikan dengan penerapan logo Galamedia. Tidak hanya itu, sebagai pendukung bentuk penunjukan arah ke atas, maka terdapat garis-garis berwarna biru dan kuning yang mewakili garis pada logo Galamedia. Hal tersebut membentuk karakteristik dari kantor Galamedia sehingga identitas yang dikeluarkan sangat jelas. Kemudian, usulan desain yang juga mendekati objek yaitu wayfinding B. Hal tersebut juga dapat diterapkan, contohnya pada lantai 2 atau 1 koridor kantor Galamedia.

\subsection{Hasil Akhir Desain Wayfinding pada Dinding Koridor Kantor Galamedia}



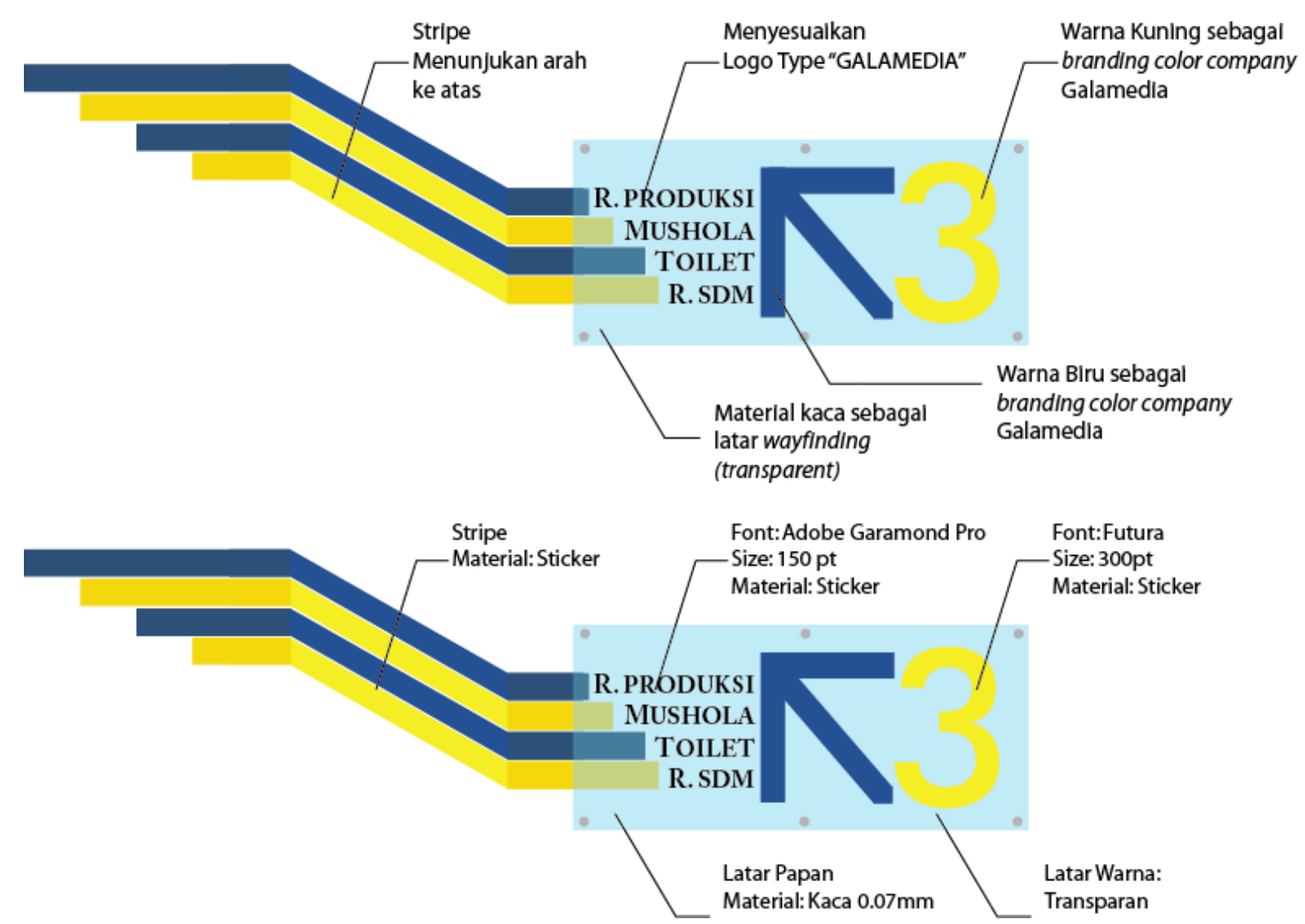

Gambar 10. Penyesuaian Desain dan Pemilihan Material Wayfinding

Pada gambar diatas, dapat dijelaskan bahwa penerapan wayfinding disesuaikan dengan logo Galamedia seperti penggunaan warna dan logo type, sehingga identitas perusahaan dapat disampaikan dengan jelas dan membentuk karakteristik. Untuk pemilihan logo type diterapkan pada teks konten informasi untuk menyesuaikan bahwa hal tersebut merupakan informasi yang paling utama, sehingga mengikuti apa yang ada pada logo Galamedia dengan logo type Adobe Garamond Pro dan pemilihan warna hitam sebagai warna teks ditujukan untuk menegaskan informasi yang disampaikan bahwa terdapat ruang produksi, mushola, toilet dan ruang SDM di lantai 3. Selain itu, pemilihan warna yang ditujukan untuk membentuk karakteristik dan branding color company Galamedia yaitu menerapkan dominan warna kuning dan biru sehingga pengguna akan lebih mudah mengenal identitas kantor. Warna kuning dan biru diterapkan pada informasi lantai dan petunjuk arah karena akan lebih terlihat lebih kontras dari warna latar yang diterapkan. Sebagai pendukung bentuk juga diterapkan garis yang menunjukan ke arah atas dengan warna kuning dan biru, hal tersebut juga dimiliki pada logo Galamedia.

Dalam pemilihan material utama yaitu menggunakan lapisan stiker (waterproof), hal tersebut akan memudahkan pihak kantor dalam melepas atau memasang stiker kembali karena kecenderungan adanya pengubahan tata letak ruang kantor sehingga informasi yang disampaikan akan berubah. Selain itu, penggunaan material kaca transparan sebagai material papan informasi ditujukan agar memudahkan sistem lepas dan pasang sehingga tidak merusak banyak elemen dinding ketika adanya pengubahan warna cat koridor serta memiliki kesan yang berbeda jika dibandingkan hanya menggunakan stiker. 


\subsection{Ilustrasi Desain Wayfinding pada Dinding Koridor Kantor Galamedia}

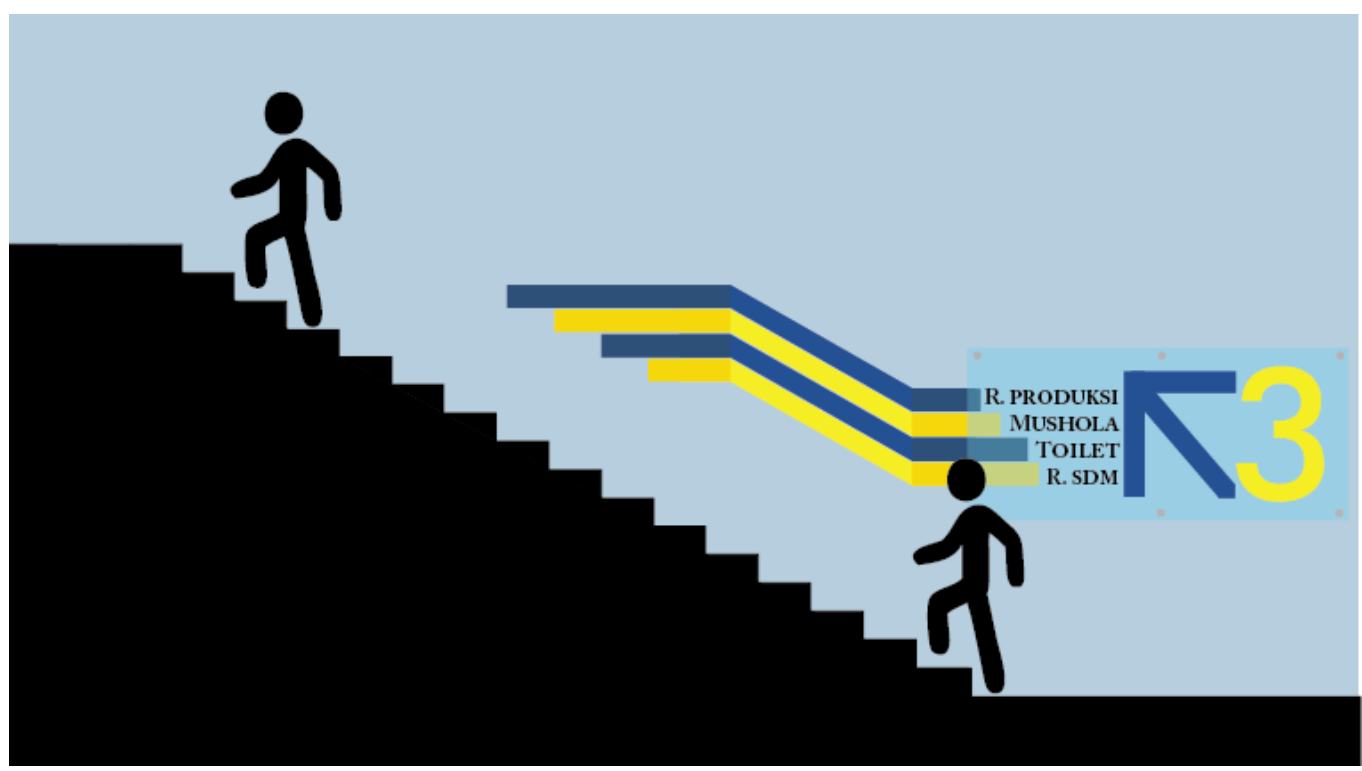

Gambar 11. Ilustrasi Desain Wayfinding pada Koridor Kantor Galamedia

Ilustrasi gambar diatas menunjukan bahwa bentuk wayfinding pada koridor terlihat sangat tegas dari segi peletakan, bentuk maupun penggunaan warna yang disesuaikan dengan eksisting ruangan dan karakteristik Galamedia. Peletakan wayfinding pada dinding akan mempermudah pengguna dalam mencari informasi karena menyesuaikan dengan jalur sirkulasi ruangan menuju lantai 3 yang terdiri dari ruang publik, seperti ruang produksi, ruang SDM, toilet dan mushola. Dengan adanya wayfinding tersebut juga memberikan suasana kantor yang lebih efektif, terutama untuk pengunjung maupun pengguna lama yang datang ke kantor tersebut.

\section{Kesimpulan}

Dari keseluruhan data penelitian ini, dapat disimpulkan bahwa identitas perusahaan seperti logo dapat memberikan karakteristik ke dalam penerapan wayfinding. Jika ditinjau kembali berdasarkan studi kasus, ruang koridor Galamedia memiliki desain yang monoton dari segi elemen dinding, lantai dan langit-langit sehingga ruangan pun tidak menciptakan identitas perusahaan, sedangkan identitas perusahaan sangat dibutuhkan dalam memanajemen kantor untuk meningkatkan kualitas dan berpengaruh terhadap psikologi pengguna. Identitas perusahaan dapat diwujudkan melalui logo perusahaan karena memiliki pengaruh besar yang dimiliki oleh perusahaan. Penerapan logo Galamedia di bidang eksternal sudah tepat sasaran, akan tetapi dalam pengaplikasian secara internal (desain ruang) tidak maksimal. Artinya, pernyataan logo Galamedia tidak disampaikan secara desain di dalam ruang terutama bagian koridor yang menjadi sirkulasi publik dan penghubung ruang satu dengan lainnya. Pengaplikasian interior tidak hanya melibatkan bidang interior melainkan bidang grafis seperti penerapan wayfinding yang memiliki tujuan untuk memberikan infomasi dengan menggunakan petunjuk arah yang didukung dengan teks padat, jelas, dan singkat sesuai lokasi ataupun tata letak ruang. Hal tersebut akan memudahkan bagi pengguna publik mencari lokasi dalam situasi sendiri terlebih bagi pengguna baru. Namun, untuk pengguna lama juga akan menciptakan suasana koridor yang efektif. 
Penerapan wayfinding di dalam ruang koridor kantor Galamedia terdiri dari beberapa komponen penting seperti konten dan lokasi, bentuk layout, sistem desain grafis, dan material. Dalam menerapkan konten informasi di dalam kantor Galamedia menyesuaikan lokasi yang akan menjadi tujuan dalam wayfinding yaitu lantai 3 sebagai tujuan, sedangkan papan informasi akan diterapkan di lantai 2 menuju koridor. Pemilihan lantai 3 sebagai tujuan lokasi dikarenakan lantai tersebut memiliki ruang yang cukup padat dibandingkan lantai sebelumnya, seperti ruang produksi, ruang SDM, toilet dan mushola. Bentuk yang diterapkan yaitu persegi panjang sebagai bentuk layout papan informasi. Hal tersebut berkaitan dengan bentuk yang minimalis dan menyesuaikan bentuk di lapangan. Tidak hanya itu, penerapan desain grafis juga dikaitkan dengan adanya logo perusahaan (branding color company) Galamedia yaitu biru dan kuning serta penggunaan logo type "GALAMEDIA" yaitu Adobe Garamond Pro. Hal tersebut memberikan suasana yang sesuai dengan perwujudan perusahaan serta dapat membentuk identitas dan karakteristik. Untuk menunjang material yang digunakan akan lebih baik jika menggunakan material kaca dan laminasi stiker sebagai material utama. Pemilihan material tersebut dikarenakan kecenderungan pihak perusahaan untuk mengubah cat warna dinding sehingga material kaca dan laminasi stiker dapat di lepas-pasang dan untuk perawatannya pun tidak sulit, hanya dengan menggunakan air dan cairan pembersih debu.

\section{Referensi}

[1] Adir, G., et al. 2012. Logo design and the corporate identity, Procedia Social and Behavioral Science 51: hal 650-654

[2] Calori, C dan Eynden, D.V. 2015. Signage and wayfinding design (2nd edition). Wiley. New Jersey

[3] Coenen, J., et.al. 2016. Synchronized wayfinding on multiple consecutively situated public displays. The $5^{\text {th }}$ International Symposium on Pervasive Displays. June 20-22, 2016. Oulu, Finland

[4] Machado, J. C, 2015. Brand logo design: examining consumer response to naturalness. Journal of Product \& Brand Management, Vol 24 lss 1 pp

[5] Mihajlovic, A., et.al. 2016. The importance of responsive logo design across a wide range of devices on the web. Sinteza 2016. International Scientific Conference on ICT and EBusiness Related Research, April 22, 2016, Belgrade.

[6] Misoska, A.T., et al. 2014. Workspace as a factor of job satisfaction in the banking and ICT industries in macedonia. Serbian Journal of Management. Vol.9: hal 159-171.

[7] Poulin, R. 2012. Graphic design + architecture. Rockport Publishers, Massachusetts

[8] Salmi, P. 2016. Wayfinding design: hidden barriers to universal access. Implications. A Newsletter by InformeDesign Vol. 05 Issue 08. University of Minnesota

[9] Sugiyono. 2013. Memahami Penelitian Kualitatif, CV Alfabeta, Bandung 